\title{
Only one way to swim? The offence and the life course in accounts of adaptation to life imprisonment
}

Ben Jarman (https:/ /orcid.org/0000-0003-3527-5437)

University of Cambridge Institute of Criminology

Word count

9,842

Current version

Author's original version (12.8.2019)

Corresponding author

Ben Jarman

Address

University of Cambridge Institute of Criminology, Sidgwick Avenue, Cambridge CB3 9DA, United Kingdom

Telephone

$+44(0) 1223335360$

Fax

$+44(0) 1223335356$

Email

bmhj2@cam.ac.uk

\section{Abstract}

Recent studies of long-term imprisonment describe a largely invariant pattern of prisoner adaptation. This article, based on a qualitative study of men serving life sentences in England, argues that adaptation may in fact vary more than these studies imply, both because of the prisoner's age when sentenced, and because of the circumstances of particular offences. Participants engaged differently with the prison's rehabilitative 'offer', depending on how the sentence affected the life course, and what they understood to be the moral ramifications of the offence. These findings refine our understanding of adaptation, and suggest that a renewed focus on prisoners' moral reflexivity may bear fruit in future research.

Keywords:

long-term imprisonment, indefinite imprisonment, life imprisonment, rehabilitation, moral reflection, murder 


\section{Introduction}

The UK is one of Europe's leading users of indeterminate imprisonment (van Zyl Smit and Appleton 2019:355-64). This situation has resulted partly from a broad legal definition of murder (which attracts a mandatory life sentence), partly by tariff inflation, ${ }^{1}$ and partly by 'backdoor sentencing' which makes it harder to get (and stay) out of prison (Padfield 2005). Spans of imprisonment once thought outlandish are now routine: nearly a quarter of over 8,500 lifers are serving tariffs of at least twenty years (Prison Reform Trust 2018:6, 28), when thirty years ago such sentences were seen as outlandish and extreme.

This unprecedented situation has spurred new empirical research on long-term imprisonment (henceforth, LTI), with the significant recent finding that there is a consistent process of adaptation and adjustment. This appears to be generated by individual prisoners' reflection on 'existential' ${ }^{2}$ questions prompted by the sentence: how can life be worth living in such radically altered circumstances, after previously anticipated futures have been cancelled, in circumstances which are often felt to be self-inflicted? Although the adaptation process is consistent, it is easy to conclude from recent research that it is also invariant. This article uses data from a qualitative study of life-sentenced prisoners (henceforth, 'lifers') to question that implication.

The argument is threefold. First, I argue that existential reflection has different consequences depending on how a long prison sentence impacts the life course. I base this point on comparisons between lifers sentenced at different ages, comparisons not made in other recent analyses. Second, I argue that existential reflection has different consequences depending on the degree to which lifers experience stigma and shame arising from the offence. This point draws on an empirical discussion of the varied moral ramifications of involvement in different kinds of offence. Woven into these arguments is a third: that both life stage and shame arising from the offence affect compliance with rehabilitative sentence requirements. Indefinitely-sentenced prisoners are required to participate in rehabilitative programming, and some find these requirements painfully 'tight' (Crewe 2011a). Release on parole is tied to satisfactory performance, inducing compliance with the expectation to change even among those who doubt the extent of their guilt, or deny any moral imperative to do so. In making this third argument I draw on the insight that compliance takes many forms, not all of which signal equal legitimacy (Bottoms 2002). Not all lifers shoulder moral censure (Duff 2001) or take responsibility for the offence in the same way.

My overarching aim is to refine earlier findings by describing in greater depth the 'moral reflection' (Schinkel 2014) underpinning adaptation. While supporting the finding that lifers and long-term prisoners (henceforth, LTPs) undergo widespread and distinctive shifts in agency, my analysis questions whether these in fact represent 'only one way to swim' (participant quoted in Crewe, Hulley, and Wright 2017a:525).

\footnotetext{
1 The 'tariff: the minimum term, the shortest possible period of imprisonment.

2 That is: '[o]f, relating to, or concerned with individual human existence [...] having, or prompted by, a keen awareness of individual freedom and responsibility' (OED n.d.)
} 
In what follows, I review relevant literature, identifying three key recent findings and the questions they beg. I then describe the research and outline how lifers convicted of different events and with different personal biographies respond to the notion that they ought to change. Finally, I suggest what these findings might mean for future research in the area.

\title{
Literature review
}

\author{
'[L]ife-course and criminal career research has largely failed to document psychological, social, \\ and behavioural changes that occur during periods of incarceration. This oversight is particularly \\ noteworthy in the case of individuals serving long sentences, as they spend a significant portion of \\ the life course behind bars.' (Kazemian and Travis 2015:355)
}

Research into the effects of LTI conducted in the 1970s and 1980s differed over whether and how to account for the subjective experience of imprisonment. For quantitative researchers measuring empirical variables such as reaction time and psychological constructs such as selfesteem (Banister et al. 1973; MacKenzie and Goodstein 1985; Rasch 1981; Sapsford 1979, 1983; Zamble 1992), no substantial detriments could be found among those who had served more of their sentences. The finding that LTI was effectively harmless became a 'reigning paradigm' (Liebling and Maruna 2005:2), marginalising less replicable qualitative research (e.g. Cohen and Taylor 1972; Sykes 1958) which nevertheless argued that the existential 'pains of imprisonment' were a major determinant of the prison experience.

More recently, the evaluative context has changed. Mass imprisonment, sentence inflation, and the growth of life-without-parole (LWOP) sentences have revitalised scholarly interest, discrediting the proposition that imprisonment does no harm. Recent research has tended to employ a qualitative or mixed methods approach, describing and/or measuring the severity and meaning attributed to the 'pains of imprisonment' at different points in the sentence (Herbert 2019; Hulley, Crewe, and Wright 2016, 2019; Crewe et al. 2017a; Crewe, Hulley, and Wright 2017b; Wright, Crewe, and Hulley 2017; Liem 2016; Schinkel 2014; cf. Flanagan 1980, 1981; Richards 1978). The broad consensus is that LTI produces a certain modal subjectivity: people '[change] drastically during the course of [a long] prison sentence' (Kazemian and Travis 2015:376), typically into a distinctive kind of person, highly self-controlled, capable of not offending, but often ill-equipped for and disappointed by life after release, though the processes that lead to this outcome remain underexplored. Some have argued that these changes are so significant that they call for a new psychiatric diagnosis, 'post-incarceration syndrome' (Liem and Kunst 2013).

Since the longitudinal research Kazemian and Travis call for is lacking, recent cross-sectional studies offer the best available evidence base. Taken together, they suggest three significant findings.

First, patterns of agency and identity observable at different sentence stages are consistent with a very widespread adaptation process holding 'very consistently, virtually regardless of other variables' 
(Crewe et al. 2017a:538). ${ }^{3}$ Adaptation, on this account, is fairly invariant. Early-sentence-stage prisoners suppress or deny the reality of their predicament, or channel feelings about it into other activities. Their reflexive focus is on the past, and what has been lost. Later, these adaptations shift: the 'pains' of imprisonment persist but ease somewhat, and lifers 'begin to find purpose and meaning' (Crewe et al. 2017a:537) by focusing more on the future. A move from 'reactive' to 'productive' agency (ibid.) is well-supported by other studies. It is accompanied by the adoption of routines and practices offering 'a modicum of control' and allowing lifers 'to fashion a life at least partly on their own terms' (Johnson and Dobrzanska 2005:9). For Irwin (2009:66), shifts of this kind are moments of 'awakening'; for Liem (2016:99-103) they are 'epiphanies'; and for Herbert (2019:28), 'maturation' and the 'recognition of interdependency'. Their timing is quite individual (Irwin 2009:66-67), but for most they are irresistible: even those who question the fairness of their predicament find that 'sentiments of bitterness and desperation' (Crewe et al. 2017a:538) are simply incompatible with survival.

Second, recent studies tend to agree that by the later stages of their sentences, most lifers become self-controlled, compliant and biddable, or 'easy to keep' (Herbert 2019). They favour solitary pursuits, avoid influences they see as 'impulsive, disruptive, and even dangerous' (Johnson and Dobrzanska 2005:10), and embrace strikingly 'generative' aims (see Maruna, LeBel, and Lanier 2004) which they are nevertheless often hard-pushed to realise after release (Appleton 2010; Liem 2016; Schinkel 2014). Such changes are also manifest among prisoners serving LWOP sentences (Cunningham and Sorensen 2006; Johnson and McGunigall-Smith 2008; Leigey and Ryder 2015; Sorensen and Reidy 2019), who lack the incentive to work towards freedom, but like other lifers have a large stake in 'liveability': whether the conditions of prison life support a meaningful, tolerable existence. Thus 'easy-to-keepness' is likely to be caused partly by prolonged exposure to the prison environment, and not simply induced by the allure of official incentives.

Third, many recent studies have foregrounded LTPs' private and interior reflexivity, describing this variously as 'existential introspection', 'serious introspection', or 'solitary reflection' (respectively, Crewe et al. 2017a:537; Irwin 2009:77; Schinkel 2014:40-45). For some prisoners, time to think is a significant positive in the prison experience (Schinkel 2014:40-44). But the emphasis here is on cognition severed from its accustomed social context (see Crewe and Ievins 2019), while selfhood is in 'a state of fragmentation' (Liem 2016:99), or in a 'liminal' state similar to being diagnosed with a chronic or terminal illness (Jewkes 2005). The past is torn away, the future cancelled, and sources of meaning, esteem and worth (such as family, work or material consumption) are attenuated or removed altogether. These privations constitute an 'offence-time nexus' and an 'adaptive imperative', impelling reflection on one's predicament; discernment of where one's own responsibility might lie; acceptance of what one cannot change; accountability for what one can; and the adoption of some 'cause, vocation or ideal' which can lend meaning to the experience (Crewe et al. 2017a:537-39; Wright et al. 2017:238). Sometimes these reflections proceed to the extent that past life is re-evaluated as 'fundamentally wrong' (Irwin 2009:66). But feelings of guilt are not a necessary precondition for such changes of heart: even prisoners who

\footnotetext{
${ }^{3}$ An important exception is those — as many as a fifth of lifers eligible for one study — who do not adapt but disintegrate psychologically, either taking their own lives or passing into secure psychiatric care (Crewe, Hulley, and Wright 2017a:520, 524).
} 
maintain their innocence often maintain that imprisonment was 'the best thing that ever happened' to them (Irwin 2009:105), finding paradoxical ways to take responsibility for actions they nonetheless steadfastly deny (Hulley et al. 2019).

These findings shed some light on the developmental questions posed by Kazemian and Travis (2015:363-70), who suggest making greater use of desistance research in theorising the developmental processes at work among LTPs. Here, I draw two key insights from it, one relating to each half of Wright et al.'s (2017) 'offence-time nexus'.

The first relates to the life course. Desistance is associated with transitions into adult roles involving responsibility for others: work, parenthood, and marriage in particular (e.g. Laub and Sampson 2003). Much desistance theory (e.g. Bottoms and Shapland 2014; Giordano, Cernkovich, and Rudolph 2002; Weaver 2016) rests on such 'cognitive transformations'. For example, an imprisoned parent might in some circumstances seek rehabilitative intervention, hoping better to live up to that role (Schinkel 2019). But a prison sentence is a form of 'suspended animation', in which life goals are (at best) put on hold; a very long sentence exaggerates these effects. LTI not only disrupts parenting ties for those who already have children, but also confines others beyond the horizon of their biological fertility (see Crewe et al. 2017b). Both complicate the scope for parenting to be experienced as a source of meaning and hope. Likewise, any sense of worth derived from work is effectively ended by a long sentence: much prison work is unrewarding, and advanced age, complex licence conditions, the risk of recall to prison and offence disclosure requirements can make finding work after release difficult (e.g. Liem 2016). Developing Jewkes's (2005) metaphor of chronic illness, adaptation to a long sentence can be thought of as adaptation to a lifechanging injury. Though any resulting 'disability' is socially determined (see Burke, Collett, and McNeill 2019), its impact will differ substantially with age and prior 'health'. Such individual variations are invisible in studies of adaptation, either because their samples were convicted young (and hence, conceivably, were better able to envisage a worthwhile life after prison - see Crewe, Hulley, and Wright 2020), or because age was not prominent in the analysis (e.g. Appleton 2010; Liem 2016).

The second insight I draw from desistance theory relates to the 'offence' in the 'offence-time nexus' (Wright et al. 2017), and specifically to shame and stigmatisation. For lifers and LTPs, 'changed identity' cannot mean simply the negation of an 'anti-social' or 'criminal' identity in favour of a 'pro-social' or 'non-criminal' one, though binary definitions of this kind feature in some theories of desistance (e.g. Paternoster and Bushway 2009). Not all lifers and LTPs possess a 'criminal' identity in the first place, which is more common among persistent and not necessarily serious offenders (McNeill and Weaver 2010:5). Second, and more importantly, criminal identity is imposed by a long prison sentence and associated post-release conditions: lasting or lifelong disclosure requirements, surveillance and supervision, travel restrictions can all be experienced as painful (and sometimes irrelevant) forms of stigma (see McNeill 2019b). They can restrict employment and economic opportunities after release (Appleton 2010), but also personal relationships (Liem and Weggemans 2018), resulting in lasting and pervasive dilemmas about disclosing one's past (Aresti, Eatough, and Brooks-Gordon 2010). Adaptation therefore involves a combination of 'agency and resignation' (Crewe et al. 2017a:530), centring on acceptance of these life-altering consequences. If 'coming to terms with being a murderer [involves] the 
management of shame' (Crewe et al., 2017a, p.530), then the term 'management' is significant: shame is controlled or taken charge of, rather than dispelled, ignored or neutralised. Here again, the sentence is a life-changing injury: it inflicts a socially-determined disability whose affective and practical burden must nevertheless be borne by individuals possessing different resources and capabilities. Existing research offers some evidence that different kinds of shame arising from different kinds of offence can result in different management strategies: such issues structure the prison experience of men convicted of sexual offences (Ievins 2017), and mark out different 'desistance pathways' for those convicted of differently-stigmatised offences (F.-Dufour and Brassard 2014).

In sum, though there may be an 'offence-time nexus' (Wright et al. 2017) centred on the offence of murder and its heavy sanction, we might guess that neither the offence itself nor the time burden it generates will put the same questions to all. Like desistance, the process of adaptation might be visible in the aggregate, but its trajectory might be shaped by life as lived before and anticipated after the sentence (cf. Schinkel 2019). Those who feel less ashamed by the past might experience demands for rehabilitative change as 'tight' and painful misrecognitions (Crewe 2011b; cf. McNeill 2019a); those who find the past more shameful might resent them less. Those who anticipate a lonely, poor, ailing and stigmatised existence after prison might doubt that 'rehabilitation' is promised in its dictionary sense: the 're-establishment of the reputation or merit of a person' or the 'restoration of a person to former privileges' (OED n.d.).

These guesses are difficult to evaluate using existing empirical accounts of adaptation, which offer limited insight into how aggregate patterns of agency might be individually different.

Generating such insight is my focus in the remainder of this article.

\section{The study}

Fieldwork was conducted in 2017 at HMP Gartree, a male prison housing only people serving indeterminate sentences. To be eligible, participants needed:

- a tariff of at least ten years, of which at least two had already been served;

- two or more convictions before the index offence, and

- not to have been recalled to prison following release on licence

The aim was a sample possessing a 'criminal identity' before imprisonment, with long sentences to serve, but past the shock and disorientation of the very early sentence stages. Because of my interest in the life course, I wanted to sample for wide variation not only on sentence stage, but also life stage. I therefore used an anonymised list of eligible prisoners and calculated a modified version of O'Donnell's 'pain quotient' (or 'PQ' - see O'Donnell, 2014, pp.201-5) for each case on the list. ${ }^{4}$ Cases were ranked on PQ and divided into quartiles, then further subdivided into

\footnotetext{
${ }^{4}$ This study was not an empirical test of PQ and it was not a key concept in the analysis. But O'Donnell's coefficient— $\left(P Q=\frac{\text { time to be served }}{\text { life to be lived }}\right)$ —aims to capture objectively the subjective burden of prison time, 
quartiles on age when sentenced. Sixteen individuals (one from each subdivision) were randomly selected and sent information sheets.

As is common in prison research, sampling plans went somewhat awry: it became clear during interviews that the anonymised list had been generated without one eligibility criterion, as some interviewees had no previous convictions. It was impractical to resolve this problem in the time available, so the eventual sample comprised eighteen men: thirteen selected randomly as above; and five more approached purposively. All eighteen were lifers convicted of murder, but nine had no previous convictions and only five had two or more as originally envisaged. The sample therefore varied unanticipatedly, in that only some interviewees described anything resembling 'criminal identity' before prison.

Interviews were semi-structured and qualitative, ranging from 42 to 145 minutes in length and averaging 93. Structuring themes were drawn from the desistance literature; the interview solicited a description of life before prison (but not a full life history) before asking the interviewee to reflect on the sentence in light of the notion of personal change: did it matter to them; what hindered or supported it; how did they evaluate rehabilitative interventions; and how did they relate personal change to prison social life more generally?

Their evaluations of other prisoners, of prison personnel, and of the offence suggested that personal change could be a moral (and not simply an instrumental) imperative: descriptions of participation in prescribed offending behaviour programmes (henceforth, OBPs) were very varied: some complained that the courses were a 'catch-22' damning those who did them and those who did not; others spoke of them enthusiastically as a place in which to do important 'work'. These differences of emphasis resulted in changes to my initial NVivo code list, with the analysis proceeding by iterations of deductive and inductive thinking (see Layder 1998).

The sampling difficulties mean that what follows should be interpreted cautiously. While the sample was broadly representative of the eligible population at Gartree (see Table 1), it varied widely not only on age and sentence stage (as intended - see Table 2), but also on criminal record and identity (unintended). As a result, the phenomenon under examination evolved: from how lifers with lengthy criminal records prepared for desistance after release, to how lifers in general reckoned with imposed stigma.

\section{[TABLES 1 AND 2 ABOUT HERE]}

Because the sample was small, and diverse in unforeseen ways, theoretical saturation (Marshall 1996) could not be assumed. The arguments below should therefore not be read as definitive or exhaustive. Nevertheless, there were clear patterns in the data.

and was therefore used as a replicable basis on which to blindly select cases. I used a published dataset (World Bank n.d.) to estimate life expectancy for the sample. 


\section{Results and discussion}

\section{The sentence and the life course}

Because past studies relied either on young samples, or did not make age a central variable in the analysis, how the sentence affects the life course might have been underplayed as a factor in adaptation. In this section I compare adaptation among lifers who were younger and older when sentenced.

Accounts of adaptation among younger lifers resonated with earlier descriptions (e.g. Crewe et al. 2017a) of a move towards more future-oriented forms of agency:

I want to have a family, you know? That's all I want. My father was an evil fucking bastard. My mum was damaged from all the things that happened to her. But my kids will never have that [...] I know I can be an awesome dad [...] I know I can help people. I just want someone to love, you know?' (Davidas, twenties, $P Q 3 / 46)^{4}$

I didn't want to [interact with prison staff]. I didn't like it. But [supervisor] said: "listen, what's the matter with you? When you get out, what are you going to do? You're going to be working, what are you going to say to your manager? 'I feel uncomfortable? Listen, you're going to have to interact with people outside your social circle." He was right, you know.' (Regis, twenties, $P Q 11 / 46)$

These descriptions conceptualised the sentence as a hiatus in the normal life course, and were anchored in the possibility that prison offered time in which to prepare for a distant, though nonetheless hopeful future. Also in keeping with earlier studies, adaptation involved the development of emotional moderation and self-control, discovered through private reflection more often than it was sought through interventions:

Especially on the wing, when [...] someone says something, and you just have to walk off [...] It's hard, man. [A] non-criminal person will think nothing of it, whereas you feel that [...] you've been mugged off [...] Y Yu just feel like a dickhead. I'll be [on] the cooker [and someone will say] "that's my pot, take [yours] off, get it fucking off there", and you go 'I don't want to know, mate" [...] I walk away from it, it's the best thing to do.' (Owen, thirties, PQ 6/42)

Such accounts of how the daily temptations and provocations of prison life had been dealt with over time predominated in the accounts of lifers younger when sentenced. Self-control and moderation were key characteristics to 'work on'; the more distant goal of 'rehabilitation' was seen as relating more to work and education than to OBPs. Some criticised the prominence of the latter in rehabilitative provision:

The money could be spent better on [...] bricklaying courses, motor mechanics, woodwork, electricians [...] When people get out of prison, and they go for a job, [what are they going to]

\footnotetext{
${ }^{4}$ In quotes attributed to prisoners, a pseudonym, a rough age, and O'Donnell's PQ are given, with the latter in the form "years to tariff expiry/remaining years of life expectancy".
} 
say? 'Well, I ain't got no qualifications, but you know, I've done Resolve, and I've got Enhanced Thinking Skills, whatever". [They're not going to get the job]' James, forties, PQ 9/30)

Even so, most engaged pragmatically, gleaning what they could (discussed further below) but also harbouring private grievances about provision focusing more on the past than the future.

This was in stark contrast to men who had been convicted in their late thirties and forties. Like their younger peers, many were well-adapted and felt they were progressing in their sentences. But they remained preoccupied by the past:

If you've spent most of your life hating your father, because you thought he was a real bad person, and then [...] you suddenly come to the conclusion that you're worse than [bim] - trust me, that's a change.' (John, fifties, PQ 9/9)

This differed from Davidas's outwardly similar reference to his father, because for John the comparison rebounded onto him. In middle age when sentenced, his children - now adultswanted nothing to do with him. He and the other older men had come to feel that they had failed to live up to their own ideals of fatherhood. Worse, this realisation had come when it was too late to do otherwise. Their narratives of change were highly retrospective, unlike the futurefocused 'productive' agency of the younger men (cf. Crewe et al. 2017a). Far from 'knifing off the past (Laub and Sampson 2003), they wanted to integrate it with who they now recognised themselves to be. Their self-evaluations were holistic and often scathing:

For over a decade I didn't commit an offence, so to speak, [but] that doesn't mean that my life wasn't deeply immoral, in ways you can't be prosecuted for.' (Max, forties, PQ 12/29)

The actions of a past self they no longer identified with had become hard to account for, resulting in a sense of alienation:

\section{If someone sits in front of you and wants to know why you did [the offence], they're not interested in, "I-don't-knows" or "I'm-sorrys". You've got to come up with some logical explanation. And I think that's where it can get difficult. It can really get difficult.' John, fifties, PQ 9/9)}

John's 'difficulty' arose from reconciling past and present, not present and future. All three older men said that experiences of 'difficulty' like these had become overwhelming; they had all been pointed by prison staff towards interventions which had helped make sense of them. They had not only participated in long-term therapeutic interventions (as opposed to shorter cognitivebehavioural courses), but they described these with striking enthusiasm (explored further below). They were not only compliant with the demand that to earn release by changing, but also saw it as morally legitimate:

I don't want to be released yet [...] I will try my damnedest [but if] I weren't ready, I'll refuse parole. If it comes to it, I'd rather die in prison, than commit another victim.' (Martin, forties, PQ 12/24) 
So far, I have argued that adaptation varied according to how the sentence affected the life course. Yet it was difficult to attribute these variations entirely to age, because the men sentenced in mature adulthood had all committed similar offences, ${ }^{5}$ making analytical contrasts between them difficult. I therefore turn now to discussing the effects on variation of the offence itself.

\section{Stigma and the offence}

Wright et al. (2017) describe how early-stage lifers commonly experience 'intrusive recollections' of the offence. Adaptation during the early sentence stages, they suggest, defends against flashbacks of this sort; later-stage adaptations represent a kind of identity work aiming to manage the shame associated with them (see Crewe et al. 2017a). It is plausible enough that emotions such as guilt, shame and regret involve similar physiological sensations. But their cognitive processing into moral sentiments is highly individual, drawing on personal experiences and histories (Nussbaum 2001). Here, therefore, I extend Wright et al.'s analysis, asking how grappling with the notion that one is 'a murderer' might vary according to the specific murder one is convicted of. I describe how men who seemed to experience differing degrees of shame reckoned with the requirement to change, and to comply with rehabilitative sentence requirements.

At its simplest, 'defensiveness' simply meant the denial of responsibility. Luke said that the court had recognised his co-defendant as having struck the lethal blows. He saw the prison's rehabilitative offer as being made in bad faith, and was aggrieved at being pushed to participate in interventions that (in his view) misrecognised his true nature: ${ }^{6}$

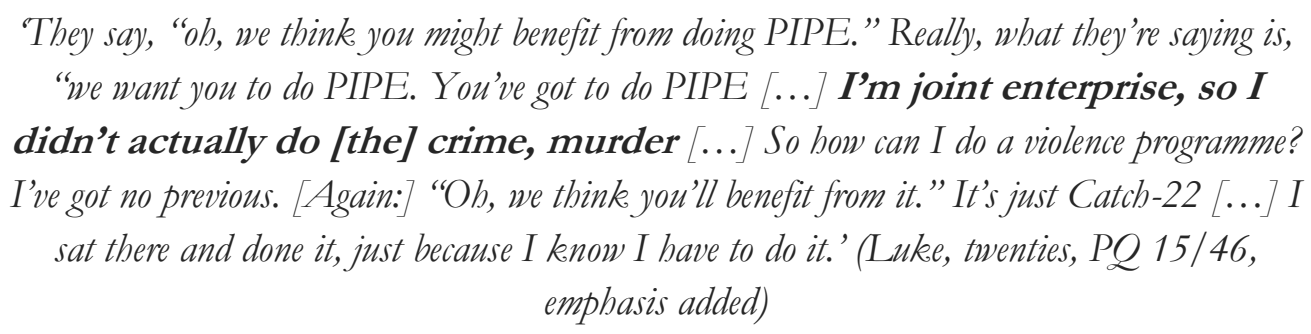

His compliance with rehabilitative expectations was entirely instrumental: a drudgery necessary to free him from prison.

Six others (including all five in the sample who were pursuing legal appeals) admitted some form of responsibility, but saw 'tight' sentence conditions as illegitimate, irrelevant, morally alien, or something for another time:

I was just a very normal guy, before this all happened [...] [Someone who] doesn't think about criminal things, basically [...] I just don't believe that I should be doing any courses. [But eventually] I think I'm probably planning on doing [Thinking Skills], because I probably didn't think as much as I should have. But there's no point in doing all of the

\footnotetext{
5 They had all killed a family member.

${ }^{6}$ Others with similar convictions see them as illegitimate, while also taking limited (and paradoxical) forms of responsibility (Hulley et al. 2019). Luke might have been earlier in this process.
} 


\section{thinking skills near the beginning [of the sentence] because you might forget. And anyway, it doesn't really mean anything.' (Pete, fifties, PQ 19/18, emphasis added)}

These men found it hard to reconcile a public position of innocence with any form of rehabilitative compliance. They acknowledged the brute reality that this position would eventually have to soften, but struggled to reconcile this with an idea of 'rehabilitation' that (as Pete put it) 'mean[t] anything'. Others who (unlike Pete) had prior convictions were less bothered by being called 'criminals', but still resented the label 'murderer'. Typically, they admitted taking a life, but implied provocation, described extenuating circumstances ignored or dismissed at trial, or remained silent. Such accounts took responsibility but disputed blame: references to recklessness, immaturity, 'things getting out of hand' or 'a mistake' (James) were common. The audience was invited to accede to the narrator's moral worldview, and/or to conclude that he had already 'learned his lesson', rendering further punishment persecutory, excessive and redundant. Among men whose accounts of the offence were exculpatory, OBPs were for another time, perhaps following the exhaustion of legal appeals. As Pete's words (above) suggest, the sheer length of the sentence often facilitated procrastination.

Other participants took fuller forms of responsibility, accepting (albeit often conditionally) the basic moral legitimacy of punishment. Strategies for managing shame were patterned on the circumstances of the offence and the identity of the victim.

For some, murder had been a by-product of other criminal activity, usually connected with the drug trade. An existing (and sometimes acrimonious) relationship between offender and victim meant that questions of '[m]oral character and causal primacy' were blurred (Rock 1998:189), at least in memory and lived experience if not always in the version of events presented at trial. These men accounted not for the offence itself but instead their wider involvement in crime. Accounts of childhood adversity featured often:

'I knew [my father], we know each other... But obviously, he had a drinking problem. Which
obviously took most of his time and attention. So we didn't really have a strong relationship.' (Michael, twenties, PQ 18/46)

I was just lost in the world, I had no one to show me the right way [...] I grew up in care, and [...] I was just looking up to drug dealers [...] and gang bangers, and all this [...] I was just like, volatile, impulsive, and just not a good person.' (Andy, thirties, PQ 5/40)

Three further features of these narratives were striking. First, the offence tended to be described not as inherently shameful, but instead as a by-product of misguided values, since forsworn:

'My whole lifestyle and motivation was just money, money, money. But money's not everything.' (Regis, twenties, PQ 11/46)

Second, these men characterised prison life in strikingly moral terms. The prison was 'full of evil' (Regis). However, the location of 'evil' varied: for most, it was manifest among (some) other prisoners; but for some, especially those who had spent long periods in high-security prisons, prison staff and 'the system' were immoral and malign, rather than simply amoral or indifferent: 
I was Cat-A up until [recently] They've [milked] that Cat-A status [...] It's bullshit. It's a scam [...] It's a relief to be out of there but I feel about the poor people that are in [highsecurity prisons] [...] There's people in Cat-A that are in wheelchairs [...] They're abusing the system, man. It's sick. It's disgusting, it's not right [...] I just don't know how it runs. It's disgusting, man. It's sick.' (Andy, thirties, PQ 5/40)

Third, change itself was described as a 'battle' (Regis) or a 'struggle' (Owen). Who- or whatever the adversary, 'goodness' was proved in the prison's crucible. Stories linking personal privations to ethical dilemmas, and investing the self with moral worth, were very common:

'I lost my job and for months] I was struggling — I couldn't even buy toothpaste! [...] I saw people [dealing drugs], I could have easily approached them [...] I went through a whole week, I was up all night walking around my cell, constantly disputing [...] I was THIS close! I was SO close! [But] I thought to myself, "you know what, I'm not gonna do it." That was hard, man! That was hard!' (Regis, twenties, PQ 11/46)

Most such reflection was done in private, often in the cell. It was dramatic, and its outcomes appeared intensely meaningful. But unlike those who denied the implications of their guilt, these men recognised that change also required a public face. One 'battle' was therefore against misrecognition: a common complaint was that prison psychologists were remote, inobservant, and attentive to the distant past, not to the drama unfolding on the prison's stage. Opportunities to have experiences of change endorsed and given credence were therefore rare, and recognition was slow to follow:

\section{$\mathrm{R}:{ }^{7}$ When I was stabbed at [prison], I [made] a statement, [and] the assailants what done that to me got convicted. So [prisoners] seen me as a grass, that can't be trusted. [But] that was for me to show them, "listen, man, I'm not involved in this no more. I'm stepping away". And it}

\section{took a long time to actually get [prison staff] to see that.}

BJ: What were you stepping away from?

$\mathrm{R}$ : The prison life of respect and the code on the wings.

Among these men, engagement with OBPs was pragmatic, but rather than being dismissed out of hand, their legitimacy was evaluated course-by-course and session-by-session:

'ETS, a load of shit. It's just common sense [...] FOCUS - look, I don't drink or do drugs anyway, I SOLD drugs [...] A complete waste of the taxpayer's money! [...] I don't smoke or do anything, I drink decaf coffee, I don't even drink caffeine! [But] SCP was a good course, because it really let me look back at myself. That was a good course, I won't disrespect that.' (Andy, thirties, PQ 5/40)

\footnotetext{
${ }^{7}$ Details omitted to preserve anonymity.
} 
They were trying to dig at something that wasn't there [...] every session, this woman asked me, am I part of a gang? To the point that [someone] I didn't even know [...] a white man from Yorkshire, had to stick up for me! He said, "listen, he's told you a hundred times, he's not in a gang" [...] It was starting to drain me, cos it was like every session, every one-to-one [...] she's trying to find ways to phrase it differently, like I'm retarded. And I'm like, "what's the matter with this woman?"' (Regis, twenties, PQ 11/46)

Both quotes show a different kind of rehabilitative compliance than Luke's: still instrumental (because they participated no matter what), but also somewhat normative (because they conceded the need to change, while still patrolling and defending the boundaries of the self). Where courses met their self-defined needs, these men, as Andy suggested, would not 'disrespect' them but instead recognise their legitimacy.

For others, accounting for the offence seemed more challenging. Two subgroups were apparent here: first, men convicted in youth or young adulthood of murders involving outbursts of random violence against strangers; and second, men convicted in mature adulthood whose victims had been intimate partners or family members. Both were distinguished by speaking not of a criminal (and external) value system which they could simply repudiate, but instead of interior faults:

'You have to sort of [...] agree that you are that scumbag, in a way. I kicked the head of a guy who didn't fight back. It was a shitty thing to do. I have to realise that. I can say, "I always try to do good, I am still good, good, good...” Well, you know what? I could have been better, you know?' (Davidas, twenties, PQ 3/46)

This quotation is typical of the younger subgroup, in that it recognised a stranger's 'disrespect' to have been a feeble pretext for lethal violence. This made the offence itself dishonourable and persistently troubling: knowing that 'someone's died because of you' meant knowing that life as it had been lived before 'couldn't go on any more' (Owen). As Davidas suggested, they 'had to agree' that stigma was deserved.

For the older men, the victim was known, and close. The offence was not only dishonourable and troubling, but vividly traumatic, despite the intervening years.

In my cell, at night, everything turned off, not being able to sleep [long pause] [repeats grisly details of the offence] It's [...] flying around my conscience. I couldn't stop thinking about it [...] that's when I went to see Psychology [and] I said [... I I need somebody to talk about all this [...] They said, "what do you mean?" I said, "let's put it this way: my head's fucked."'

(Martin, forties, PQ 12/24) 
Admitting to such murders appeared anguishing, and generated intense feelings of loss, shame, and 'disenfranchised grief. ${ }^{13}$ All three older men described how these feelings had pushed them to seek help. Deep experiences of shame led not outwards to bad influences and forwards to a better future, but backwards and inwards, in hope of redeeming a reprehensible self by understanding the past. The resulting reevaluation of past life was highly moralising, closer to the 'self-inventories' described by Irwin (2009) than to emotional moderation or maturation (e.g. Crewe et al. 2017a; Herbert 2019; Johnson and Dobrzanska 2005).

For both subgroups, compliance with OBPs was unambiguously normative. They participated enthusiastically, inquiringly, and even with relief. Psychological and therapeutic interventions offered social forms of reflexivity, and new ways to make sense of a senseless past. In particular, these men sought (and had completed, and praised) therapeutic interventions, including Gartree's Therapeutic Community (the GTC), for facilitating not only reduced risk (though this was valued too), but an appreciation for other people as autonomous subjects in their own right. Such insights were painful yet redemptive: they salvaged meaning from the wreckage left by the offence, and aligned moral values with those that they felt should have obtained all along:

\section{'[T] he average person outside prison, they may find this stupid, but it meant so much to me... I lacked empathy [...] And I had to make a decision, in front of [people on the GTC], to virtually just say, "I agree with you, I don't really understand empathy." And I had to go away, and for a period of two years, try and understand what empathy was [...] I never knew none of those things [...] it's not something that you can just go on a course and tick a few boxes and say, "yeah, yeah, I know what empathy is now." It [...] opened things up [...] I could start understanding my perception of other people, and theirs of me. I could understand what damage I'd caused other people and how they were feeling, whereas before [...] my attitude was always, "oh, they'll get over it."” (John, fifties, PQ9/9)}

As with Andy and Regis above, interventions were invested with meaning because they met needs the prisoner himself had defined. But for those who felt deeply ashamed, self-defined needs had far greater scope. Social forms of reflexivity - in which shame could be owned up to, rather than simply contained — seemed to generate reconciliation to the fact of punishment:

\section{People gripe on about, "yeah, I've lost my freedom, I can't be there for my family". But on the out—without the changes that I've made in jail_knowing them, internalising them-I don't think I'd have given a shit. So all the things which are important to me now, I don't think they would ever have been important. I really don't know if I've lost anything that matters [by being} in prison].' (Max, forties, PQ 12/29)

\footnotetext{
13 'Experienced by those who incur a loss that [cannot be] openly acknowledged, publicly mourned or socially supported' (Doka 1999), 'disenfranchised grief' for a person one has killed seems an exemplary case.
} 
Other prisoners (even prison personnel) were described as partners in personal change, generating a certain sense of reciprocal obligation:

'W]ithout [everybody in the TC], staff, prisoners, the rest, I wouldn't have been able to do it.
It's like an engine, if one little bit's not working right, the whole thing'll break down. It's all got
to work together. Else it won't work.' (John, fifties, PQ 9/9)

Unlike men whose reflection was more private, and who longed for their narratives of change to be endorsed, GTC graduates appeared to find misrecognition less threatening, and chafed at the laxity of those who (as they saw it) were ducking the duty to work on themselves: as Max put it, 'you've got amends to make, just fucking get on with it'. This perhaps disparaged the fear beneath others' reluctance to do this kind of self-disclosing 'work':

\section{Discussion}

For Crewe et al. (2017a), whose sample were 25 or under when sentenced, adaptation to LTI is largely a reflexive shift: from resistance to a form of conditional acceptance, or 'swimming with the tide'. Like grieving, it involves 'letting go' aspects of past identity, and 'letting in' feelings about the offence and the sentence, hopefully without becoming inundated. My argument in this article is that the adaptation process is more differentiated than this account might suggest, and that the fear of inundation may relate to two further variables: age when sentenced, and the nature of the offence.

In the first case, this is because of how massive sentences distort the normal life course. Younger men, who could envisage a viable life after prison, saw the prison as a proving ground. Its rehabilitative offer was evaluated on that basis (and not usually positively): most, unless pushed, preferred to leave the past where it was; but they also wanted more in terms of preparation for the future. By contrast, older men had less (temporally and figuratively) to look forward to. Their 'moral reflection' (Schinkel 2014) was retrospective: they pondered, often in perplexity, what it meant to have lived lives so defined by irreversible harm. It was clear regardless that for men of nearly all ages, the incentive of release powerfully induced rehabilitative compliance, however relevant, legitimate or useful what was on offer seemed. But this was not so for the oldest man in the sample, Desmond (seventies, PQ 6/-8): frail and in failing health, he expected to die in prison and saw his offence as a private matter ('I'm not here through my own fault, but I'm not going into that'). He declined any form of sentence planning or rehabilitative activity, and this position was tenable because the unreality of release loosened the prison's grasp on his subjectivity.

\footnotetext{
${ }^{8}$ Details omitted to preserve anonymity.
} 
In the second case, I have argued that the nature of the offence gives rise to different approaches to the 'management of shame' (Crewe et al., 2017a, p.530). Some accepted it normatively, while others managed it pragmatically. Because rehabilitative compliance was so widespread, this distinction could mainly be observed in how notions such as 'rehabilitation' or 'change' were described by different people. Descriptions of OBPs were a rich seam of such descriptions, and usually signalled a normative evaluation (cf. Bullock and Bunce 2018:6-9; Crewe 2009:149-245; Ievins 2017:72-112). Across the entire sample, stories abounded of some prisoners attending courses, 'telling them what they wanted to hear' (James), and even paying other prisoners to 'do the homework' (Richard). In some tellings, such shenanigans were offered as evidence of the uselessness and fraudulence of rehabilitative provision; in others, the prisoners who engaged in them were hypocrites of dubious character. Between these extremes, prisoners like Andy and Regis (quoted above) reserved the right to evaluate the courses piecemeal. Such distinctions are not mere niceties: they offer empirical evidence that some offences are experienced as more shameful than others, and that there may be corresponding ways to manage stigma.

\section{Conclusion}

My argument should be read with caution. The variations in the sample were not those envisaged or planned for; the sample was small; and it was possible to triangulate details of participants' offences only through media reports. ${ }^{9}$ Linking these findings to official assessments of risk was therefore impossible, though will be a focus in the research for which this was a pilot study.

Even on this basis, however, the notion of an invariant adaptation process may require modification. 'Imported' distinctions such as life stage and offence type-which for Crewe et al. (2017a:538) are 'more or less flattened' by the 'sheer heft' of the act of murder and the 'severity of the sanction that follows' - in fact alter adaptation, at least as it relates to moral communication and rehabilitation, which are both key aims of punishment (Canton 2017).

In relation to the life course, these findings draw attention to personal teleology: what meaningful goal or 'ground project' (Mattingly 2014) do lifers themselves imagine, and how does this affect their ethical work on themselves? If younger lifers focus on the realisation of a better future self (Crewe et al. 2020), this may follow from their being young, not necessarily from adaptation to imprisonment. Older lifers in this study sought meaning by more closely focusing on the past. Some felt they had squandered 'generative' opportunities such as family and career, one expected to die in prison, and others worried that life after release would be a lonely decline. Working to reduce criminogenic risk paled somewhat against these concerns.

In relation to the offence, these findings draw attention not simply to the fact that lifers reflect on the moral ramifications of their offences (as argued by, among others, Crewe et al. 2017a; Irwin 2009), but also to the specific content of these reflections. Penal theorists commonly agree that punishment communicates censure (e.g. Duff 2001), but they continue to debate how far this entails a normative demand for change (e.g. Bottoms 2019). It is also open to question-and an empirical question-whether censure is actually conveyed in practice (Schinkel 2014:13-61).

\footnotetext{
${ }^{9}$ Coverage of the trial was found for all but one cases.
} 
Most lifers in this study engaged with the demand to rehabilitate themselves, but their compliance with it was not always normative (Bottoms 2002), and hence did not always demonstrate the legitimacy of those demands, which entails dialogue (Bottoms and Tankebe 2012; Brownlee 2011). All of this should draw our attention to how the offence is situated in personal biography.

Not all in this study experienced their categorisation as 'dangerous', 'criminals', 'murderers' or simply 'bad people' as a form of misrecognition (see McNeill 2019a). The extent to which they did depended on how faithfully these negative judgments reflected their own view of themselves. Those who saw censure as unjustified managed shame; those who felt it was justified accepted it, a significant distinction. However privately culpable they felt, though, wider moral discourses set the terms in which 'bad' actions could be situated in coherent (and public) narratives of change.

We know from empirical research that lifers commonly come to pursue what they imagine to be a good life in prison; but as has been argued elsewhere (King and McDermott 1990; Liebling and Williams 2017), a narrow focus on risk and dangerousness can cause prisoners' own ethical work - their attempts to imagine and live a 'good life' in prison- to go unnoticed or misunderstood, with serious consequences for meaningful assessments of their progress. As Williams (2018) goes on to suggest, recent anthropological work on ethics and morality (e.g. Keane 2016; Laidlaw 2013; Mattingly 2014) offers criminologists the conceptual and methodological resources with which to make better sense of these attempts.

Recognising the import of prisoners' own moral and ethical evaluations about their offences and sentences does not mean that, in any objective sense, some murder(er)s are 'better' than others. But evaluative descriptions asserting that this is indeed the case are ubiquitous, in both legal and lay discourse: for example, they feature in sentencing guidelines (Crown Prosecution Service n.d.), making them central determinants of the severity of punishment. This is reason enough to take them seriously as empirical facts. The impact of a life sentence is measured not only in time, but also in denigration. Since the impact of neither is softened by claims of rehabilitative intent, closer attention is required to how lifers negotiate with both.

\section{Acknowledgements}

Thanks to Ben Crewe for helpful comments on an earlier draft of this article.

\section{Funding}

The author received no financial support for the research, authorship, and/or publication of this article

\section{References}

Appleton, Catherine. 2010. Life after Life Imprisonment. Oxford: Oxford University Press. 
Aresti, Andreas, Virginia Eatough, and Belinda Brooks-Gordon. 2010. 'Doing Time after Time: An Interpretative Phenomenological Analysis of Reformed Ex-Prisoners' Experiences of Self-Change, Identity and Career Opportunities'. Psychology, Crime \& Law 16(3):169-90.

Banister, P. A., F. V. Smith, K. J. Heskin, and N. Bolton. 1973. 'Psychological Correlates of Long-Term Imprisonment: I. Cognitive Variables'. The British Journal of Criminology 13(4):312-23.

Bottoms, Anthony E. 2002. 'Morality, Crime, Compliance and Public Policy'. in Ideology, crime and criminal justice: a symposium in honour of Sir Leon Radzinowicz, Cambridge criminal justice series, edited by A. E. Bottoms and M. H. Tonry. Cullompton: Willan.

Bottoms, Anthony E. 2019. 'Penal Censure, Repentance and Desistance'. P. 33 in Penal censure: engagements within and beyond desert theory, Studies in penal theory and penal ethics; volume 7, edited by A. du Bois-Pedain and A. E. Bottoms. Oxford, UK; Portland, Oregon: Hart Publishing.

Bottoms, Anthony E., and Justice Tankebe. 2012. 'Beyond Procedural Justice: A Dialogic Approach to Legitimacy in Criminal Justice'. The Journal of Criminal Law and Criminology 102(1):119-170.

Bottoms, Anthony, and Joanna Shapland. 2014. 'Can Persistent Offenders Acquire Virtue?' Studies in Christian Ethics 27(3):318-33.

Brownlee, Kimberley. 2011. 'The Offender's Part in the Dialogue'. Pp. 54-67 in Crime, Punishment, and Responsibility: The Jurisprudence of Antony Duff, edited by R. Cruft, M. H. Kramer, and M. R. Reiff. Oxford University Press.

Bullock, Karen, and Annie Bunce. 2018. “'The Prison Don't Talk to You about Getting out of Prison": On Why Prisons in England and Wales Fail to Rehabilitate Prisoners'. Criminology \& Criminal Justice 20(1):111-27.

Burke, Lol, Steve Collett, and Fergus McNeill. 2019. Reimagining Rehabilitation: Beyond the Individual. 1st ed. New York: Routledge.

Canton, Rob. 2017. Why Punish? An Introduction to the Philosophy of Punishment. London: Palgrave.

Cohen, Stanley, and Laurie Taylor. 1972. Psychological Survival: The Experience of Long-Term Imprisonment. Harmondsworth: Penguin.

Crewe, Ben. 2009. The Prisoner Society: Power, Adaptation and Social Life in an English Prison. Oxford; New York: Oxford University Press.

Crewe, Ben. 2011a. 'Depth, Weight, Tightness: Revisiting the Pains of Imprisonment'. Punishment \& Society 13(5):509-29.

Crewe, Ben. 2011b. 'Soft Power in Prison: Implications for Staff-Prisoner Relationships, Liberty and Legitimacy'. European Journal of Criminology 8(6):455-68.

Crewe, Ben, Susie Hulley, and Serena Wright. 2017a. 'Swimming with the Tide: Adapting to Long-Term Imprisonment'. Justice Quarterly 34(3):517-41. 
Crewe, Ben, Susie Hulley, and Serena Wright. 2017b. 'The Gendered Pains of Life Imprisonment'. The British Journal of Criminology 57(6):1359-78.

Crewe, Ben, Susie Hulley, and Serena Wright. 2020. Life Imprisonment from Young Adulthood: Adaptation, Identity, Time. London: Palgrave Macmillan.

Crewe, Ben, and Alice Ievins. 2019. 'The Prison as a Reinventive Institution'. Theoretical Criminology https://doi.org/10.1177/1362480619841900.

Crown Prosecution Service. n.d. 'Sentencing - Mandatory Life Sentences in Murder Cases (Legal Guidance)'. The Crown Prosecution Service. Retrieved 12 August 2019 (https://www.cps.gov.uk/legal-guidance/sentencing-mandatory-life-sentences-murdercases).

Cunningham, Mark D., and Jon R. Sorensen. 2006. 'Nothing to Lose? A Comparative Examination of Prison Misconduct Rates Among Life-Without-Parole and Other LongTerm High-Security Inmates'. Criminal Justice and Behavior 33(6):683-705.

Doka, Kenneth J. 1999. 'Disenfranchised Grief. Bereavement Care 18(3):37-39.

Duff, R. Antony. 2001. Punishment, Communication, and Community. Oxford: Oxford University Press.

F.-Dufour, Isabelle, and Renée Brassard. 2014. 'The Convert, the Remorseful and the Rescued: Three Different Processes of Desistance from Crime'. Australian \& New Zealand Journal of Criminology 47(3):313-35.

Flanagan, Timothy J. 1980. 'The Pains of Long-Term Imprisonment: A Comparison of British and American Perspectives'. The British Journal of Criminology 20(2):148-56.

Flanagan, Timothy J. 1981. 'Dealing With Long-Term Confinement: Adaptive Strategies and Perspectives Among Long-Term Prisoners'. Criminal Justice and Behavior 8(2):201-22.

Giordano, Peggy C., Stephen A. Cernkovich, and Jennifer L. Rudolph. 2002. 'Gender, Crime, and Desistance: Toward a Theory of Cognitive Transformation'. American Journal of Sociology 107(4):990-1064.

Herbert, Steven Kelly. 2019. Too Easy to Keep: Life-Sentenced Prisoners and the Future of Mass Incarceration. Oakland, California: University of California Press.

Hulley, Susie, Ben Crewe, and Serena Wright. 2016. 'Re-Examining the Problems of Long-Term Imprisonment'. The British Journal of Criminology 56(4):769-92.

Hulley, Susie, Ben Crewe, and Serena Wright. 2019. 'Making Sense of "Joint Enterprise" for Murder: Legal Legitimacy or Instrumental Acquiescence?' The British Journal of Criminology 59(6):1328-46.

Ievins, Alice. 2017. 'Adaptation, Moral Community and Power in a Prison for Men Convicted of Sex Offences'. PhD, University of Cambridge, Cambridge.

Irwin, John. 2009. Lifers: Seeking Redemption in Prison. New York: Routledge. 
Jewkes, Yvonne. 2005. 'Loss, Liminality and the Life Sentence: Managing Identity through a Disrupted Lifecourse'. Pp. 366-88 in The effects of imprisonment, edited by A. Liebling and S. Maruna. Cullompton: Willan.

Johnson, R., and A. Dobrzanska. 2005. 'Mature Coping Among Life-Sentenced Inmates: An Exploratory Study of Adjustment Dynamics'. Corrections Compendium (December):8-38.

Johnson, Robert, and Sandra McGunigall-Smith. 2008. 'Life Without Parole, America's Other Death Penalty: Notes on Life Under Sentence of Death by Incarceration'. The Prison Journal 88(2):328-46.

Kazemian, Lila, and Jeremy Travis. 2015. 'Imperative for Inclusion of Long Termers and Lifers in Research and Policy: Forgotten Prisoners'. Criminology \& Public Policy 14(2):355-95.

Keane, Webb. 2016. Ethical Life: Its Natural and Social Histories. Princeton [New Jersey]: Princeton University Press.

King, Roy D., and Kathleen McDermott. 1990. "My Geranium Is Subversive”: Some Notes on the Management of Trouble in Prisons'. The British Journal of Sociology 41(4):445.

Laidlaw, James. 2013. The Subject of Virtue: An Anthropology of Ethics and Freedom. Cambridge: Cambridge University Press.

Laub, John H., and Robert J. Sampson. 2003. Shared Beginnings, Divergent Lives: Delinquent Boys to Age 70. Cambridge, MA; London: Harvard University Press.

Layder, Derek. 1998. Sociological Practice: Linking Theory and Research. London: Sage.

Leigey, Margaret E., and Michael A. Ryder. 2015. 'The Pains of Permanent Imprisonment: Examining Perceptions of Confinement Among Older Life Without Parole Inmates’. International Journal of Offender Therapy and Comparative Criminology 59(7):726-42.

Liebling, Alison, and Shadd Maruna. 2005. 'Introduction: The Effects of Imprisonment Revisited'. Pp. 1-32 in The Effects of Imprisonment, edited by A. Liebling and S. Maruna. Cullompton: Willan.

Liebling, Alison, and Ryan J. Williams. 2017. 'The New Subversive Geranium: Some Notes on the Management of Additional Troubles in Maximum Security Prisons'. The British Journal of Sociology 69(4):1194-1219.

Liem, Marieke. 2016. After Life Imprisonment: Reentry in the Era of Mass Incarceration. New York: New York University Press.

Liem, Marieke, and Maarten Kunst. 2013. 'Is There a Recognizable Post-Incarceration Syndrome among Released “Lifers”?’ International Journal of Law and Psychiatry 36(3-4):333-37.

Liem, Marieke, and Daan Weggemans. 2018. 'Reintegration Among High-Profile Ex-Offenders'. Journal of Developmental and Life-Course Criminology 4(4):473-90.

MacKenzie, Doris Layton, and Lynne Goodstein. 1985. 'Long-Term Incarceration Impacts and Characteristics of Long-Term Offenders'. Criminal Justice and Behavior 12(4):395-414.

Marshall, Martin N. 1996. 'Sampling for Qualitative Research'. Family Practice 13(6):522-526. 
Maruna, Shadd, Thomas P. LeBel, and Charles S. Lanier. 2004. 'Generativity behind Bars: Some "Redemptive Truth" about Prison Society.' Pp. 131-151 in The generative society: Caring for future generations., edited by E. de St. Aubin, D. P. McAdams, and T. Kim. Washington: American Psychological Association.

Mattingly, Cheryl. 2014. Moral Laboratories: Family Peril and the Struggle for a Good Life. Berkeley: University of California Press.

McNeill, Fergus. 2019a. 'Mass Supervision, Misrecognition and the "Malopticon"”. Punishment \& Society 21(2):207-30.

McNeill, Fergus. 2019b. Pervasive Punishment: Making Sense of Mass Supervision. First edition. Bingley, UK: Emerald.

McNeill, Fergus, and Beth Weaver. 2010. Changing Lives? Desistance Research and Offender Management. Glasgow: Scottish Centre for Crime and Justice Research.

Nussbaum, Martha C. 2001. Upheavals of Thought: The Intelligence of Emotions. Cambridge: Cambridge University Press.

O’Donnell, Ian. 2014. Prisoners, Solitude, and Time. Oxford: Oxford University Press.

OED. n.d. 'Existential, Adj.' OED Online.

OED. n.d. 'Rehabilitation, n.' OED Online.

Padfield, Nicola. 2005. “'Back Door Sentencing”: Is Recall to Prison a Penal Process?” The Cambridge Law Journal 64(2):276-279.

Paternoster, Raymond, and Shawn D. Bushway. 2009. 'Desistance and the "Feared Self": Toward an Identity Theory of Criminal Desistance'. Journal of Criminal Law and Criminology 99(4):1103-1156.

Prison Reform Trust. 2018. Bromley Briefings Prison Factfile Autumn 2018. Prison Reform Trust.

Rasch, Wilfried. 1981. 'The Effects of Indeterminate Detention: A Study of Men Sentenced to Life Imprisonment.' International Journal of Law and Psychiatry 4(3-4):417-431.

Richards, Barry. 1978. 'The Experience of Long-Term Imprisonment - An Exploratory Investigation'. The British Journal of Criminology 18(2):162-69.

Rock, Paul. 1998. 'Murderers, Victims and "Survivors": The Social Construction of Deviance'. The British Journal of Criminology 38(2):185-200.

Sapsford, Roger J. 1979. Life-Sentence Prisoners: Deterioration and Coping. Milton Keynes: Open University Faculty of Social Sciences.

Sapsford, Roger J. 1983. Life Sentence Prisoners: Reaction, Response and Change. Milton Keynes: Open University Press.

Schinkel, Marguerite. 2014. Being Imprisoned: Punishment, Adaptation and Desistance. Palgrave Macmillan. 
Schinkel, Marguerite. 2019. 'Rethinking Turning Points: Trajectories of Parenthood and Desistance'. Journal of Developmental and Life-Course Criminology 5(3):366-86.

Sorensen, Jonathan R., and Thomas J. Reidy. 2019. 'Nothing to Lose? An Examination of Prison Misconduct Among Life-Without-Parole Inmates'. The Prison Journal 99(1):46-65.

Sykes, Gresham M. 1958. The Society of Captives: A Study of a Maximum Security Prison. Princeton, NJ: Princeton University Press.

Weaver, Beth. 2016. Offending and Desistance: The Importance of Social Relations. First Edition. London : New York: Routledge, Taylor \& Francis Group.

Williams, Ryan J. 2018. 'Finding Freedom and Rethinking Power: Islamic Piety in English High Security Prisons'. The British Journal of Criminology 58(3):730-748.

World Bank. n.d. 'Life Expectancy at Birth, Male (Years) | Data'. The World Bank. Retrieved 23 July 2019 (https:// data.worldbank.org/indicator/SP.DYN.LE00.MA.IN?locations=GB).

Wright, Serena, Ben Crewe, and Susie Hulley. 2017. 'Suppression, Denial, Sublimation: Defending against the Initial Pains of Very Long Life Sentences'. Theoretical Criminology 21(2):225-46.

Zamble, Edward. 1992. 'Behavior and Adaptation in Long-Term Prison Inmates: Descriptive Longitudinal Results’. Criminal Justice and Behavior 19(4):409-25.

van Zyl Smit, Dirk, and Catherine Appleton. 2019. Life Imprisonment: A Global Human Rights Analysis. Cambridge, MA: Harvard University Press. 


\section{Tables}

TABLE 1: DesCRIPTIVE STATISTICS FOR THE SAMPLE (N=18) AND THE ELIGIBLE POPULATION $(\mathrm{N}=489)$

\begin{tabular}{|c|c|c|}
\hline & Sample & Population \\
\hline Age & & \\
\hline Mean (s.d.) & $38.8 \quad(12.1)$ & $40.8 \quad(12.0)$ \\
\hline $\begin{array}{l}\text { Age when sentenced: } \\
\text { Mean (s.d.) }\end{array}$ & $31.7 \quad(11.7)$ & $33.9 \quad(12.0)$ \\
\hline $\begin{array}{l}\text { O'Donnell's PQ } \\
\text { Mean (s.d.) }\end{array}$ & 10.8 & $10.8 \quad(5.9)$ \\
\hline $\begin{array}{l}\text { Sentence type } \\
\text { Life } \\
\text { IPP }\end{array}$ & $\begin{array}{c}18 \quad(100 \%) \\
-\end{array}$ & $\begin{aligned} 478 & (98 \%) \\
11 & (2 \%)\end{aligned}$ \\
\hline $\begin{array}{l}\text { Ethnicity } \\
\text { White British }\end{array}$ & $11(61 \%)$ & $288 \quad(59 \%)$ \\
\hline $\begin{array}{l}\text { BAME } \\
\text { of which: } \\
\text { White non-British } \\
\text { Black or Black British } \\
\text { Asian or Asian British } \\
\text { Mixed } \\
\text { Other } \\
\text { Not stated/missing }\end{array}$ & $\begin{array}{ll}7 & (39 \%) \\
& \\
4 & (22 \%) \\
2 & (11 \%) \\
& - \\
1 & (6 \%) \\
& - \\
& -\end{array}$ & $\begin{array}{cc}172 & (35 \%) \\
& \\
24 & (5 \%) \\
64 & (13 \%) \\
60 & (12 \%) \\
17 & (4 \%) \\
5 & (1 \%) \\
29 & (6 \%)\end{array}$ \\
\hline
\end{tabular}

TABLE 2: FREQUENCY DISTRIBUTION OF THE SAMPLE (N=18) BY PQ RANK AND AGE WHEN SENTENCED

\begin{tabular}{|c|c|c|c|c|c|}
\hline \multirow{6}{*}{ 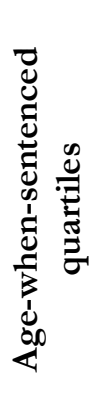 } & & \multicolumn{4}{|c|}{ PQ rank quartiles } \\
\hline & & PQR 1 & PQR 2 & PQR 3 & PQR 4 \\
\hline & AWS 1 & 1 & 2 & 0 & 0 \\
\hline & AWS 2 & 1 & 1 & 1 & 1 \\
\hline & AWS 3 & 1 & 3 & 1 & 1 \\
\hline & AWS 4 & 1 & 0 & 2 & 2 \\
\hline
\end{tabular}

